\title{
DO RIO DE JANEIRO PARA A SIBÉRIA TROPICAL: prisões e desterros para o Acre nos anos 1904 e 1910.
}

\author{
Francisco Bento da Silva*
}

\section{Resumo}

Neste artigo procuraremos trazer à tona alguns aspectos obscuros de dois acontecimentos que marcaram a nascente República brasileira no alvorecer do século XX: a Revolta da Vacina (1904) e a Revolta dos Marinheiros (1910). Alguns destes aspectos estão relacionados com as os desterros, que foram adotados como punição pelo Estado brasileiro após o fim destes eventos que ocorreram na cidade do Rio de Janeiro. O que permanece obscuro é o porquê daqueles homens e mulheres serem condenados ao desterro e o que levou o Estado brasileiro a enviá-los para o Território do Acre, na Amazônia. Objetivamos neste breve texto situar dentro das normas e enquadramentos jurídicos adotados na época, os intentos e sentidos de tais medidas. Discutindo também os significados das percepções das punições impostas aos desterrados na perspectiva da ordem republicana, bem como os propósitos — simbólicos e práticos — de serem enviados para os “confins” da Amazônia, no Acre.

Palavras-chave: Desterros. Revolta da Vacina. Revolta da Chibata. Amazônia. Acre.

\section{Prelúdio}

Quem são estes desgraçados que não encontram em vós mais que o rir calmo da turba que excita a fúria do algoz? Quem são? Se a estrela se cala, se a vaga à pressa resvala como um cúmplice fugaz,

Perante a noite confusa...

Navio Negreiro (1868), Castro Alves

\footnotetext{
* Francisco Bento da Silva é professor do Centro de Ciências Humanas da UFAC. Graduado em Ciências Sociais, com mestrado e doutorado em História. Contato: chicobento_ac@yahoo.com.br.
} 
No início do século XX, nos últimos semestres dos anos de 1904 e 1910, a cidade do Rio de Janeiro foi tomada por duas Revoltas de grandes impactos e múltiplos significados, que envolveram de forma direta e indireta vários estratos sociais subalternos que compunham àquela sociedade de então: militares de baixa patente, trabalhadores portuários, desempregados, prostitutas, capoeiras e ambulantes, entre outros sujeitos, em conflito com a ordem estabelecida. Estas revoltas ficaram conhecidas como Revolta da Vacina (1904) e Revolta da Chibata (1910).

Nas duas primeiras décadas da infante República temos a fase mais turbulenta de sua existência, segundo José Murilo de Carvalho (2004), que aborda alguns aspectos relacionados às mudanças sociais e políticas em curso no fim do XIX e nos primeiros anos do século XX. Foram medidas outorgadas de forma impositiva e à revelia da maioria da população ainda "sub-cidadã”, pois era alijada do processo de participação política ativa e se encontrava destituída de amplos direitos, que eram apenas partilhados pela elite política e econômica daquele período.

A manutenção da ordem de classe e a garantia da ordem pública se mostravam necessárias para o governo e seus apoiadores. A categoria genérica de "povo” é definida por seu comportamento ordeiro, como procura deixar claro o jornal Gazeta de Noticias. Ao mesmo tempo o jornal se refere aquilo que seria seu oposto: determinadas categorias sociais de homens e mulheres pobres que em 1904 participaram da Revolta da Vacina. Diz o periódico carioca:

povo não é o facínora que empunha a navalha, o cacetete e a garrucha; povo não é o ladrão que esvazia o bolso do transeunte e assalta as casas e rouba; povo não é o desordeiro de profissão; povo não é o ébrio habitual; povo não é a meretriz, não é o cáften, não é jogador, o vagabundo e o vadio ${ }^{1}$.

Pela abordagem ligeira e seletiva do jornal, somente a chamada escória social poderia se revoltar. O povo ordeiro não. Em ambos os acontecimentos aludidos, o poder público encarcerou milhares de pessoas consideradas criminosas e perigosas frente à ordem que a classe dirigente procurava estabelecer sobre os mais variados estratos sociais que compunham aquela sociedade multifacetada. Uma ordem notadamente centrada nos ainda infantes ideais republicanos, valores vinculados às concepções de modernidade e de civilização, em grande medida baseados nos pressupostos da belle époque francesa e da Ilustração européia adaptados aos trópicos (NEEDELL, 1993). O Brasil daquela época

\footnotetext{
${ }^{1}$ Jornal Gazeta de Notícias. Os sucessos de novembro: o relatório do chefe de polícia, ano XXXI, $\mathrm{n}^{\circ} 358$, 23/12/04. Acervo da Fundação Biblioteca Nacional.
} 
apresentava uma sociedade cindida, vista como sendo composta de adaptados versus inadaptados, educados contra ignorantes, civilizados de um lado e rudes de outro. Em resumo, as posturas, as práticas e as crenças eram dicotomizadas para estabelecer o permitido e o proibido à maioria da população de um país recém saído da escravidão. Uma Nação que pelo alto negava ao mesmo tempo o que tinha sido, mas ainda não era o que queria ou imaginava ser.

Quando aquelas duas Revoltas foram sufocadas pelo poder republicano, o destino de todos os indesejados, a maioria “criminosa sem crimes”, foi a prisão e o desterro da capital federal, enviados para um local considerado ermo, distante e de difícil retorno à "civilização republicana”: a Amazônia, nas bordas de suas fronteiras. Fronteiras que não eram apenas geográficas e físicas, mas fundamentalmente fronteiras simbólicas; fronteiras que separavam no imaginário coletivo o idilismo de uma sociedade desejada, das suas contradições e fissuras que deveriam ser eliminadas ou transferidas para lugares distantes, escondidas.

Muitos deles foram mandados em dois "navios-prisões” - Itapacy, Itaperuna e Itaipava em 1904 e o Satélite em 1910 — para a Amazônia, especificamente para o Território do Acre $^{2}$. Estes navios saíram do porto do Rio de Janeiro e navegaram por toda a costa nordestina até chegarem aos portos das cidades de Belém (PA) e depois Manaus (AM), onde os desterrados sobreviventes foram novamente encaminhados para locais mais longínquos do continente amazônico: inicialmente destinados às frentes de trabalho na Estrada de Ferro Madeira-Mamoré, na Comissão Rondon e nos seringais acreanos. Em um intervalo de seis anos, duas tragédias com personagens e roteiros semelhantes tiveram começo na capital da república e seus respectivos desfechos nas selvas amazônicas.

\footnotetext{
2 Era comum se referir à Amazônia como Inferno verde e a expressão “ir para o Acre”, no Dicionário Houaiss (2001) é sinônimo de morrer, em voga desde a segunda metade do século XIX quando chegam os primeiros migrantes na região para trabalharem na extração do látex. Muitos morriam acometidos por doenças endêmicas da região.
} 


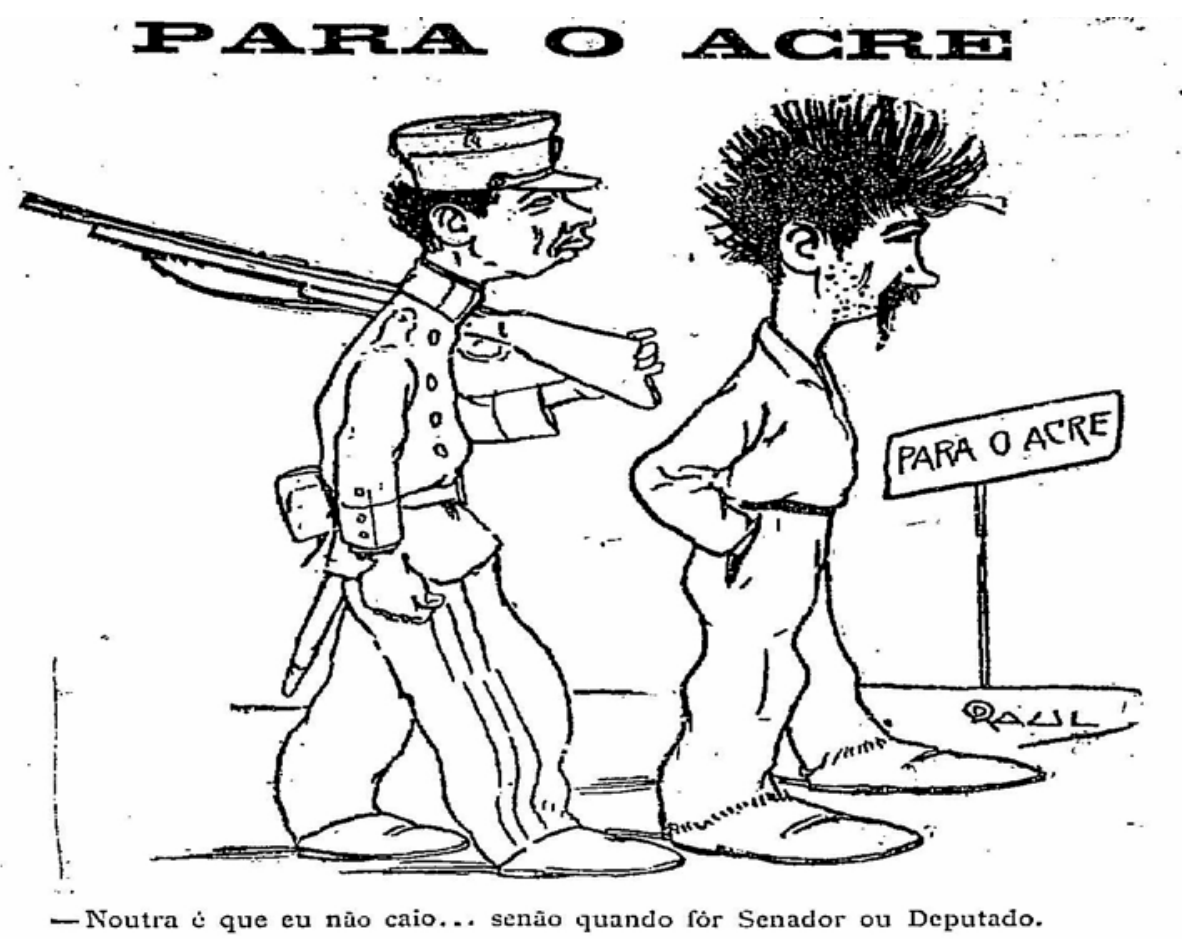

Charge 01: Para o Acre. Gazeta de Notícias, no 331, de 26/11/1904. Acervo da Fundação Biblioteca Nacional.

Relatos oficiais apontam que para o Acre foram deportadas 1400 pessoas relacionadas ao episódio da Revolta da Vacina, e 444 pessoas ligadas direta e indiretamente a Revolta dos Marinheiros. Muitos morreram na viagem por falta de condições sanitárias, brigas entre eles ou justiçados pelos militares que faziam guarda dos navios até o seu destino final. Não sabemos o número exato dos enquadrados nestes casos, mas foi algo concreto na vida e na morte destas pessoas condenadas a não serem "ninguém”: não eram cidadãos, não eram formalmente criminosos, muitos não tiveram seus nomes revelados e não tiveram seus direitos garantidos.

\section{Identificação e criminalização das classes perigosas}

No Brasil, a infante República que no alvorecer do século XX completara pouco mais de uma década, ainda estava em formação, procurando construir e inventar uma identidade que superasse, ou mesmo negasse, o passado monárquico e escravocrata. Os próceres republicanos visavam então “ajustar” o Brasil sob a ótica dos valores “civilizados” e “modernos” extraídos da tradição européia em curso há algum tempo. Para isso, irão intentar estabelecer novos valores, normas e práticas para regular e disciplinar a população e os usos dos espaços da cidade. O olhar do Estado e das elites sobre a maioria da população 
comumente vai então ser de desconfiança e temor, procurando disciplinar pelo alto os estratos sociais/laboriais considerados potencialmentes perigosos e de fácil insurgência à disciplina então requerida e desejada.

Nesta ampla classificação se enquadravam "prostitutas, ladrões, malandros, desertores e rebeldes da marinha e do exército, dos navios estrangeiros, ciganos, ambulantes, capoeiras, carroceiros, bicheiros, etc” (CARVALHO, 2004, p. 18). Se na escravidão não se permitiam homens sem senhores; com a república e a adoção do trabalho livre, não se permitiam mais homens sem patrão. Eram mais do que leis contra a vagabundagem, eram medidas que procuravam disciplinar coercitivamente posturas e criar uma tecnologia política dos corpos, com bem fala Michel Foucault na sua obra Vigiar e punir (1987).

Revoltas ou tentativas de revoltas na capital federal já vinha acontecendo desde as últimas décadas do século anterior: a Revolta do Vintém (1880), tendo como estopim o aumento do preço das passagens dos bondes; a Revolta da Armada (1893), contra os castigos infringidos aos marinheiros e ao alistamento forçados e a Revolta das carnes verdes (1902) são significativos exemplos. Medidas de expulsão e isolamentos eram as conseqüências que recaiam sobre os revoltosos, fossem civis ou militares. Havia um medo permanente, por parte das autoridades, da possibilidade de mobilizações populares e revoltas, pois no olhar republicano "um segmento da população era percebido como largamente despreparado para a vida em sociedade, pessoas que precisavam antes de educação e orientação para o 'bem'” (CHALHOUB, 1988, p. 84). Isto leva Rui Barbosa a dizer que as atrocidades da escravidão havia legado à posteridade “uma nação de libertos inconscientes” (apud CHALHOUB, p. 84). Neste grupo se inseriam basicamente negros e mestiços, vistos com desconfianças pelos republicanos devido aqueles serem comumente considerados mais ligados à monarquia finda.

Mas vamos a algumas digressões acerca dos banimentos: em 1890 o então chefe de polícia da cidade do Rio de Janeiro, Sampaio Ferraz, baniu levas de capoeiras para a Ilha de Fernando de Noronha (NASCIMENTO, 2001, p. 118), como forma de tirar da cidade - no olhar policialesco de então — os elementos considerados vagabundos, dissolutos e arruaceiros contumazes. Assim também fez o marechal-presidente Floriano Peixoto quando assumiu o governo, ao colocar em desterro alguns de seus inimigos políticos. Após decretar estado de sítio em 10 de abril de 1892, desterrou o marechal José de Almeida Barreto, então senador pela Paraíba, e os deputados José Joaquim Seabra, José do Patrocínio, tenente Thamaturgo de Azevedo, conde da Leopoldina, senadores-coronéis Jaques Ouriques e Mena Barreto, todos 
eles enviados para as distantes localidades de Cucuhy, Tabatinga e São Joaquim no estado do Amazonas. Porém, meses depois eles todos foram anistiados pelo Congresso Nacional ${ }^{3}$.

No caso da obrigatoriedade da vacinação contra a varíola, em 1904, sua implementação estava integrada a um projeto de mudanças e profilaxia que o poder público visou estabelecer na cidade do Rio de Janeiro de forma autoritária, com amplos sacrifícios para grande parte dos sujeitos oriundos das classes mais pobres. A obrigatoriedade da vacinação massiva visava combater uma doença contagiosa e letal, mas como aplicá-la nos moradores da cidade? A saída, como se sabe, foi por meio de um Decreto do poder público justificado por um discurso higienista/sanitarista do saber/poder médico; e outro, que colocava a questão em um plano mais amplo: do embate entre o moderno e o atrasado. Neste sentido, os defensores mais ardorosos da vacinação irão afirmar que a revolta foi provocada por sujeitos ignorantes, contrários aos princípios humanitários da ciência e dos homens públicos.

Mas o conjunto de posturas e os códigos disciplinadores adotados pelo poder público eram mais amplos. O então engenheiro e prefeito Francisco Pereira Passos (1902/1906) — indicado pelo presidente Rodrigues Alves —, instituiu na cidade do Rio de Janeiro outras obrigações/proibições formais que iam mais além e atingiam uma gama maior de pessoas, alterando por completo o cotidiano e os modos de vida da maioria da população. Entre outros procedimentos, foi proibida a circulação de cães vadios pelas ruas, a ordenha de vacas nas calçadas, a criação de porcos e o cultivo de hortas em casa, venda de bilhetes de loterias, soltar pipas, urinar nas ruas e cuspir no chão (CARVALHO, op. cit., p. 94). Instituise então uma espécie de “cordão sanitário” que estabeleceu lugares "limpos” e lugares “sujos”, práticas condenáveis e práticas corretas na cidade do Rio de Janeiro.

A obrigatoriedade da vacina em 1904 certamente foi o estopim para que uma população já acuada pelos desmandos das autoridades e por péssimas condições de vida e trabalho se revoltasse. Assim, em novembro de 1904, durante uma semana, a cidade ficou conflagrada. No dia 13, em meio a tiroteios, barricadas e combates de rua, 22 bondes foram destruídos e mais de 700 combustores da iluminação pública ficaram inutilizados pelos revoltosos chamados de “Quebra-lampiões”, termo cunhado pela imprensa da época. Tropas de São Paulo e Minas Gerais foram então convocadas para ajudarem a debelar a revolta coletiva que dominou a região central do Rio de Janeiro. Após a revolta, com saldo de pelos

\footnotetext{
${ }^{3}$ Diário do Congresso Nacional. Sessão de 28/05/1911, ano XXII, nº 20, p. 190. Acervo do Arquivo Nacional
} 
menos 30 mortes oficializadas, 945 pessoas foram presas e mais de $1400^{4}$ desterradas com destino ao Acre. Seis anos depois, a cidade do Rio de Janeiro se encontra conflagrada novamente. Desta vez com a chamada Revolta da Chibata.

A revolta da Chibata teve sua eclosão iniciada em 23 de novembro de 1910 na Baía da Guanabara, quando marinheiros se insurgiram contra os seus superiores hierárquicos e se amotinaram nos navios de guerra fundeados na baía. Este evento serviu para explicitar a insatisfação aos castigos que estavam submetidos os marinheiros, que na sua grande maioria era composta de homens pobres e negros, comumente alistados à força pela alta oficialidade desde a época do Império. Isto acontecia “devido a ausência de voluntários, os oficiais da Marinha aceitavam todos aqueles remetidos pela polícia (...) detidos pela suspeição de, como pobres, pertencerem às “classes perigosas”” (NASCIMENTO, op. cit., p. 56).

A rebelião foi preparada dias antes em reuniões clandestinas que aconteceram em vários pontos do Rio de Janeiro, segundo o pesquisador e jornalista Marcos Morel (2006). É lícito afirmar, de acordo com Morel, que muitos marujos, devido suas viagens ao exterior talvez tenham tomado conhecimento do levante de 1905 ocorrido no encouraçado Potemkin na Rússia. Pode ter ecoado aqui nos trópicos, entre a marujada, o exemplo dos marinheiros do porto de Odessa que se revoltaram contra a opressão dos seus superiores na marinha czarista.

O estopim que deflagrou a ação do dia 23 foi o castigo aplicado ao grumete Marcelino Rodrigues, que levou 250 chibatadas diante de todos os marinheiros por ter cometido uma falta. Ao tomar o comando dos navios de guerra Minas Gerais, São Paulo, Bahia e Deodoro, fundeados na baía da Guanabara, a marujada revoltosa assassinou quatro oficiais e deu um ultimato ao governo federal: ou se acabavam com os castigos corporais na Marinha ou eles bombardeariam a capital da República (MOREL, op. cit.). Os revoltosos chegaram a dar tiros de advertência em direção à cidade, que atingiram gravemente algumas pessoas e causaram pânico na cidade. Muitos moradores começaram então a deixar a cidade e rumaram para o interior como medo de um conflito entre as Forças Armadas e os marujos rebelados; outros, mais corajosos e curiosos, rumaram para o porto, onde alguns até aplaudiam e acenavam para os irredentistas nos navios. O governo ficou encurralado e atônito.

O Congresso Nacional, às pressas, aprova no dia 26 o fim dos castigos na Marinha e anistia todos os insubordinados (projeto de autoria do senador Severino Vieira e apresentado por Rui Barbosa). Tudo parecia resolvido, quando pouco depois, no dia 09 de dezembro, a

\footnotetext{
${ }^{4}$ Além dos presos durante a revolta de 1904, o governo fez uma "limpeza” na Casa de Detenção e embarcou centenas de presos que lá estavam para o Acre.
} 
Marinha alega ter descoberto um plano para uma rebelião e manda para a Ilha das Cobras os revoltosos que tinham sido anistiados anteriormente. O jornal Correio da Manhã assim se refere ao episódio:

uns eram transportados para a Ilha das Cobras, transformada em vasto matadouro humano, outros mais felizes, no Quartel general, enquanto que na Casa de Correcção, (...) eram escolhidas à pancada as turmas de fuzileiros dos centos e tantos enviados para lá, que se destinavam a ser torturados na ilha sinistra ${ }^{5}$.

Alguns relatos afirmam que dezessete marinheiros foram diretos para as masmorras, onde quinze destes morrem devido aos castigos cruéis que lá recebem (MOREL, op. cit.). Não se sabe quantos foram para as masmorras, sabe-se apenas que João Cândido, o "Almirante Negro", e outro marinheiro apelidado de "Pau da Lira” saem com vida dos cubículos da solitária da então chamada “Ilha do Martírio”. Depois, o governo aprisionou inúmeros marinheiros que participaram do motim e embarcou boa parte destes no navio Satéllite para a Amazônia, cujo destino final seria o Acre. Além destes, um número muito maior de civis também foi recolhidos nas ruas e prisões do Rio de Janeiro e embarcados à força.

Este fato gerou muita discussão entre parlamentares e alguns jornais, que passaram a cobrar do governo informações acerca do destino dado aos desterrados e um pronunciamento oficial do poder executivo brasileiro. No dia 26 de maio de 1911, após solicitação, o presidente Hermes da Fonseca envia a seguinte mensagem ao Congresso Nacional na abertura dos trabalhos legislativos daquele ano:

Diante da manifesta inconveniência de permanecer nesta capital, em tal momento, um tão crescido número de homens desoccupados que, junto com outros indivíduos desordeiros e contumazes no crime, constituíam uma constante à ordem pública, resolvi, como medida de prudência e fundado em o $\mathrm{n}^{\circ}$ 02, § 02 do artigo 80 da Constituição, desterrar para o Acre os mais perigosos desses ex-marinheiros e alguns dos indivíduos que a elles já se achavam ligados por naturaes e perversos instinctos. (...) não foi intenção do Governo atirar essa gente sem proteção e sem abrigo, nas florestas do Acre; não, o Governo quis lhes proporcionar, naquellas regiões, o trabalho indispensável a sua subsistência ${ }^{6}$.

A assertiva do presidente traduz uma visão que parte da premissa de ser hereditária a propensão criminosa, de existirem instintos de perversidade inerentes ao sujeito. Portanto, todos aqueles que foram presos nos dias de conflitos ou recolhidos na Casa de Detenção eram considerados irrecuperáveis. A melhor solução seria isolá-los e num ato humanitário, garantir

\footnotetext{
${ }^{5}$ Jornal Correio da Manhã. A ilha do martírio, ano X, no 3.466, 13/01/11. Fundação Biblioteca Nacional.

${ }^{6}$ Diário do Congresso Nacional, op. cit., p. 190. Acervo do Arquivo Nacional.
} 
trabalho para que aqueles desterrados pudessem sobreviver o mais distante possível da sociedade que se procurava constituir. Vale ressaltar ainda que a demora pública desta discussão no parlamento, em meados do ano seguinte, se deu devido às prorrogações do estado de sítio que, entre outras conseqüências, fechou o parlamento nacional.

\section{Porque a República esconde os indesejados?}

Nos dois casos citados, os desterrados foram todos penalizados com o desterro e sem que quaisquer processos tenham sido abertos contra eles. Eram criminosos sem que crime algum fosse atribuído formalmente às suas pessoas. Tal situação era uma exceção provocada e sustentada pela instituição do estado de sítio, adotado pelo governo brasileiro nos dois episódios.

Entre os desterrados de 1904, nos jornais que fizeram a cobertura à época, aparecem apenas alcunhas dos chamados desordeiros que foram presos e banidos: o crioulo Horácio José da Silva, o vulgo Prata Preta (considerado líder das desordens em "Porto Artur”, no bairro da Saúde), Rato Branco, Truvisco, Machadinho, Almeidinha, Bombacha, Chico da Baiana, Valente, Chico Maluco, João Galego, José Moleque (José Antônio Vieira), Manduca de Luto (filho do açougueiro do bairro) e muitos outros “desordeiros” sem nomes e apenas com seus apelidos conhecidos, que somente aparecem juntos com outros silenciados nos números frios das estatísticas (PEREIRA, 2002, p. 83).

O jornal A Noticia assim narra a partida do navio Itaipava na noite do feriado do dia 25 de dezembro de 1904, quando estes deportados e muitos outros são presenteados, ainda no dia de natal, com uma viagem só de ida para o norte do país, um lugar que parte deles nem chegou conhecer, pois morreu antes:

Dos porões do navio partiam rumores surdos, gritos, imprecações, blasfêmias (...). Ali, amontoados na maior promiscuidade, crianças e velhos, negros e brancos, nacionais e estrangeiros. Nos porões nenhuma luz! Os 334 condenados, quase nus, debatiam-se nas trevas, com enormes ratazanas que, audaciosamente, os atacavam, cobrindo-os de dentadas. Nos porões os presos sem apoio rolavam uns sobre os outros, magoando-se, escorregando na lama nauseabunda de fezes e vômitos ${ }^{7}$.

O debate acerca da situação dos degredados tanto da Revolta da Vacina quanto da Revolta da Chibata gerou na capital da Republica calorosas discussões. Vejamos alguns embates e considerações a respeito dos desterrados da Revolta da Vacina colhidos dos Anais da Câmara dos Deputados.

\footnotetext{
${ }^{7}$ Jornal A Notícia, 27 de dezembro de 1904. Acervo da Fundação Biblioteca Nacional.
} 
No dia 03 de junho de 1905, o então deputado e major do exército Barbosa Lima afirma em discurso na Câmara Federal que o poder executivo, "tendo a necessidade de usar toda a força indispensável para esmagar a rebeldia que campeia no paiz, passa a ser o único

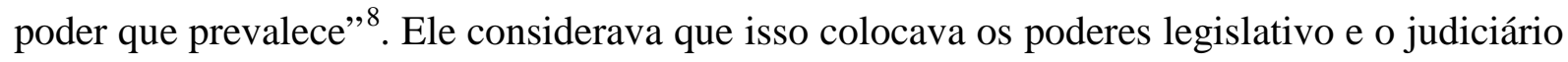
inferiores ao executivo. Levemos também em conta que a decretação do estado de sítio pelo presidente Rodrigues Alves, devido os eventos da Revolta da Vacina, exacerbou ainda mais os poderes do executivo.

Nesta mesma data o deputado Luiz Domingues protocola requerimento onde solicita do poder executivo informações sobre os desterrados para o Acre, cuja mensagem presidencial do dia 29 de maio de 1905 já afirmava: “foram, para garantia da ordem pública, retirados desta Capital para o território do Acre, como desordeiros reconhecidos e indivíduos de má reputação” (Idem, p. 24). O requerimento do parlamentar estava centrado em algumas indagações básicas, tais como: quantidade, nomes, nacionalidades dos degredados, em que trabalhavam, onde moravam, porque não foram julgados como outros indivíduos que tomaram parte do movimento, por que não foram submetidos a crimes sujeitos a fiança, etc. Depois do Estado de sítio, o Estado os traria de volta? Se eles não foram acusados do crime de desterros, que crime cometeram? Eles estavam vivos? Onde estavam?

O então deputado situacionista Garcia Pires afirma categoricamente em seu discurso que a ação do governo serviu "para a salvação da cidade e para que nos víssemos livres de um desses movimentos que, por honra nossa, deveria ser apagado das páginas de nossa história” (Idem, p. 56). Ou seja, tais acontecimentos deveriam ser esquecidos e apagados como se não tivessem existidos, silenciados da memória à posteridade para não manchar a história republicana em construção que procurava mascarar suas contradições profundas. Então complementa Garcia Pires:

Não faço injúria de dizer que os conflictos dos dias 12, 13, 14 e 15, nesta cidade, foram praticados pela população da Capital Federal. Não; os homens trabalhadores, os que concorrem para a riqueza pública, esses absolutamente não se envolveram em taes conflictos. Vi nas ruas da cidade essa classe infeliz de indivíduos que abundam em todas as capitaes, homens inteiramente despreoccupados com do sentimento da honra, noctívagos, vagabundos, batedores de carteiras; eram esses que quebravam os lampeões e atacavam as propriedades particulares. Responde ironicamente o deputado Barbosa Lima: "vi muita gente de collarinho em pé quebrando lampeões (Idem, p. 56).

\footnotetext{
${ }^{8}$ Annaes da Câmara dos Deputados, 03/06/1905, p. 20. Acervo do Arquivo Nacional.
} 
O deputado Garcia Pires finaliza sua fala usando como justificativa o fato dos conflitos terem sido perpetrados por vagabundos e sujeitos que praticavam ilícitos na capital federal havia muito tempo. Assim, ele coloca de um lado os chamados homens honrados e trabalhadores respeitáveis; de outro, aqueles que atentavam contra a ordem estabelecida e a paz urbana na capital. Tese que o deputado Barbosa Lima contesta em sua intervenção, deixando claro que não se podia dicotomizar e dizer que somente sujeitos pobres e desqualificados fizeram parte da revolta.

Em relação aos desterrados da Revolta da Chibata, ocorrida 06 anos depois, o governo utilizou o mesmo procedimento adotado para o caso anterior. Mais uma vez os parlamentares se debruçam num debate em torno dos “criminosos sem crimes" enviados mais uma vez à Amazônia. O então senador Rui Barbosa, em sessão no mês de agosto de 1911, tece seus comentários acerca dos passageiros do “navio fantasma”, o Satéllite, nos seguintes termos:

sobre o caso do navio Satélite chama o governo 'verdadeiras feras' aos 400 ex-marinheiros da nossa esquadra desterrados para o norte, nas regiões do Madeira. (...) trataram de ocultar as prisões negando-as até aos membros da Câmara dos Deputados que acudiram à polícia interessados em restituir à liberdade dos detidos (BARBOSA, 1911, p. 146).

Afirma o eminente jurista e parlamentar que devido as arbitrariedades cometidas nas prisões e a falta de informações precisas sobre os desterrados, que o Brasil era um país que ainda aspirava à condição de civilizado, mas o desterros era um fato que aviltava "o Brasil abaixo das últimas nações” do mundo.

Em seguida Rui Barbosa passa a ler uma correspondência ${ }^{10}$, que afirma ter sido enviada por uma testemunha ocular, dando lhe conta das últimas informações sobre o navio Satélite. O missivista, de nome Booz Belfort de Oliveira, justifica sua ausência prolongada da capital da República devido aos resultados negativos das eleições ocorridas em novembro do ano anterior, levando-o a dirigir-se para a região Norte a fim de realizar trabalhos como Auxiliar de Serviços Sanitários na Comissão Rondon. Confirma que estava em Belém quando soube da Revolta da Armada e depois se dirigiu à vila de Santo Antônio do Rio Madeira para atuar na Comissão Rondon, onde soube que os desterrados seriam enviados para trabalhar nesta Comissão e na construção da Estrada de Ferro Madeira-Mamoré. Segundo esta testemunha, na manhã do dia 03 de fevereiro, o coronel Cândido Rondon recebeu 200 homens

\footnotetext{
${ }^{9}$ Uso esta expressão porque os desterrados não tiveram nenhum processo criminal aberto contra eles. Foram expulsos apenas por força do estado de sítio e da acusação de desordeiros.

${ }^{10}$ A carta manuscrita [CR1071/1-12] é datada de 30/05/11, com 10 folhas, foi enviada da cidade de Olinda (PE) ao Rio de Janeiro e encontra-se na biblioteca da Fundação Casa Rui Barbosa.
} 
e o restante foi recusado pelos administradores da Estrada de Ferro Madeira-Mamoré. O navio então permaneceu ancorado e seus passageiros-prisioneiros em estado de quarentena, impedidos de descer do vapor Satéllite durante alguns dias.

Foi então constituída uma Comissão, da qual Belfort de Oliveira fez parte, que constatou a seguinte situação: "posta a prancha para o barranco, conseguimos entrar a bordo. Soubemos estarem todos recolhidos nos porões do vapor, todos prisioneiros, trezentos e tantos homens e quarenta e uma mulheres” (Oliveira, carta citada). No comando da guarda do navio estava o primeiro-tenente Matos Costa, que passa a relatar para a Comissão os acontecidos durante a viagem pela costa brasileira, principalmente a ocorrência de fuzilamentos de alguns degredados que supostamente teriam tentado criar um motim a bordo e atentado contra a vida do comandante. De acordo com o tenente Matos Costa, na saída do porto baiano, houve a eliminação de nove desterrados ${ }^{11}$ : sete por fuzilamento e dois teriam se jogado ao mar antes dos tiros. Serviram de exemplo pedagógico para obstar qualquer nova tentativa dos demais prisioneiros em criar novos tumultos nos porões (BARBOSA, op. cit., p. 154). Tudo ocorreu com carta branca do governo, segundo teria afirmado o já referido tenente Matos Costa à indagação de Belfort de Oliveira sobre aquela medida tomada.

Depois das explicações do comandante, este permitiu que os porões do navio fossem abertos. Eis o que relata nossa testemunha ocular, amiga do senador Rui Barbosa:

A guarnição formou ao longo do navio armado em guerra, de carabinas embaladas, os porões foram abertos, e, a luz de um sol amazonense (sic), os quatrocentos desgraçados foram guindados como qualquer cousa, menos corpos humanos, e lançados ao barranco do rio. Eram fisionomias esguedelhadas, mortas de fome, esqueléticas, e nuas como lêmures das antigas senzalas brasileiras. As roupas esfrangalhadas deixaram ver todo o corpo. As mulheres, então, estavam reduzidas às camisas (Oliveira, carta citada).

Então ele relata que uma porção de seringueiros $(\text { sic })^{12}$ começou a escolher aos lotes homens esfarrapados e magros, que mostravam restos de uma robustez passada, para

\footnotetext{
${ }^{11}$ Em mensagem presidencial, enviada ao Congresso em maio de 1911, o governo admite as mortes de Henrique Pereira dos Santos, vulgo Sete; Nilo Ludgero Bruno (Formiga); Isaias Marques de Oliveira, José Alexandrino dos Santos; Ricardo Benedicto; Flávio José do Bonfim (Jorge Inglez); Vitalino José Ferreira e um outro sem nome identificado. Ou seja, admite-se oficialmente apenas a morte de oito degredados, enquanto que o comandante do navio Satéllite, Carlos Brandão Storry, confirma nove em seu relatório. Diário do Congresso Nacional, op. cit.

${ }^{12}$ Certamente eram seringalistas e não, seringueiros. O seringalista era o dono ou arrendatário do seringal, onde ocorriam os trabalhos de extração do látex e da produção de borracha, que estavam a cargo dos seringueiros. O seringalista era o patrão, o seringueiro era o empregado. Mas até aquele momento, ainda não havia sedimentado o termo seringalista na linguagem corrente para diferenciá-lo do seringueiro, o que ocorre somente a partir da década de 20, segundo TOCANTINS (1982).
} 
realizarem trabalhos de cortes de seringa nos vastos seringais amazônicos. Já as mulheres, segundo o cronista, "como lobas famintas, entregaram-se a prostituição, para sustento do corpo e a estas horas talvez não existam mais” (BARBOSA, op. cit., p. 154).

Nem todos os desterrados da Revolta da Chibata eram marinheiros, a grande maioria era de civis, presos durante o período do estado de sítio ou recolhidos na Casa de Detenção. Aqueles que ficaram a serviço da Comissão Rondon, Belfort de Oliveira relata que dormiam no chão, sem agasalho ou proteção contra os mosquitos anófeles e amanheciam sob o nevoeiro de "friagens malditas". Realizavam serviços brutais sob o calor de $39^{\circ}$ celsius e careciam de alimentação compensativa às suas necessidades diárias de calorias. Inclusive, ocorrendo na própria Comissão casos de fuzilamentos como relata Belfort de Oliveira em determinada passagem da sua carta.

Terminada a leitura da carta na tribuna, Rui Barbosa passa a fazer suas considerações com apontamentos voltados à luz do direito, sua seara. Afirma a todos que tudo aquilo compunha um quadro horrendo de grosseria e desumanidade, uma abolição completa do respeito à vida, um nivelamento de seres humanos às criaturas irracionais e um desprezo “aos progressos cristãos de nosso tempo". E continua diante de todos: "Em toda minha vida política, nos quarenta anos de sua duração, é o mais cruel dos cruéis desenganos por que tenha passado a minha consciência de homem sincero” (idem, p. 159). Contudo, sua indignação e denúncia não afetam as posições defendidas pelo governo e parte da imprensa que apoiaram aquelas medidas.

Já os desterrados de 1904, pouco conhecemos sobre suas vidas no Acre. Ainda hoje, o que sabemos é que saíram com destino a esta localidade e alguns jornais acreanos atestam a chegadas destas pessoas pelo menos nas cidades de Cruzeiro do Sul e Xapuri. Resta-nos, seguir os parcos indícios deixados nas margens através de poucos documentos e fazer o diálogo possível com estes lampejos que chegaram até nós. Como é o caso do Preto Lycurgo, alcunha de Álvaro de Carvalho, que foi preso alguns anos depois na cidade de Xapuri acusado de ter cometido um assassinato naquela cidade ${ }^{13}$.

\section{Amazônia, uma terra "sem história"}

Porque a Amazônia? O olhar de grande parcela dos homens do sul do país pertencentes à intelligentsia da época — desde muito tempo estava condicionado pela idéia de

\footnotetext{
13 Autos de crime, juízo do $2^{\text {o }}$ termo da Comarca do Alto Acre, nº 268, caixa 15, 73 folhas, 1910. Fórum da Comarca de Xapuri.
} 
que a Amazônia era uma terra ignota, distante, inóspita e inadequada à presença humana. No zeitgeist (espírito do tempo) dominante à época, aqueles que nela habitavam eram considerados sujeitos que estavam em descompasso com certa visão acerca da "história nacional” e com os ideais civilizatórios, de lampejos eurocêntricos, que desembarcavam aqui nos trópicos.

O próprio antropólogo belga Claude Levi-Strauss, em sua obra Tristes trópicos, referiu-se à região como “o mundo perdido”, de populações enigmáticas, uma terra proibida e ainda desconhecida da civilização, localizada para além das franjas do sertão do Brasil central onde ele realizou seus estudos etnológicos (LEVI-STRAUSS, 2001). Talvez o título do capítulo de sua obra remeta a uma possível leitura sua da obra do escritor Arthur Conan Doyle, lançada em 1912 chamada por sinal de O mundo perdido.

Quando o escritor Euclides da Cunha tem seu primeiro contato com a Amazônia, logo ele afirma existir uma Amazônia real e outra imaginada. Esta última seria aquela presente nos relatos de cronistas e viajantes desde o XVI. No capítulo Terra sem história, de sua obra póstuma A margem da História, ele afirma que a imagem real é inferior a subjetiva, tecida ao longo dos tempos. Segundo suas impressões telúricas constituídas in loco, faltava harmonia estética, beleza equilibrada à Amazônia, portadora de uma grandeza monótona, de horizontes vazios e indefinidos numa planura desmedida (CUNHA, 2000).

Nesse meio físico que era a Amazônia, Cunha apontava que o homem chegou como um intruso impertinente. Aparecera sem ser esperado e querido, quando a natureza era ainda uma opulenta desordem. A Amazônia aparecia aos seus olhos como pertencente à outra era geológica. Mais que um descompasso temporal, havia também um descompasso civilizatório e cultural da população local. Era uma região que tinha tudo e faltava tudo (artes, ciências, história, compreensão), dizia ele. Por isso ele considera que na Amazônia o brasileiro, mesmo pisando em terras pátrias, era um estrangeiro que não fincava raízes no lugar. A própria Amazônia era uma terra sem pátria, um local selvagem que impressionava uma civilização distante, que seria o sul do país, o litoral que há muito era a antítese do Sertão (idem, ibidem).

Esta natureza brutal e soberana seria sempre uma adversária do homem: diante do homem errante a natureza era estável; para o homem sedentário, ela seria revoltosa e volúvel. Por isso, a Amazônia se caracterizava por ser uma terra de nomadismo, da inconstância que remetia à figura metafórica dos seus rios erráticos. E era/é através dos rios, que se chega(va) aos seringais, que nada mais são que um misto de paraíso e inferno na visão euclidiana. Um mundo feudal, torto e bronco em “descompasso evolutivo”. Malgrado suas idiossincrasias culturalistas, seu tom é de denúncia. 
Vejamos também como Belfort de Oliveira rememora suas impressões acerca dos degredados que ele observara desembarcando nas alastrantes terras amazônicas:

ali (na Amazônia) impera o cinismo, o crime, o contrabando e todas as misérias da humanidade (...) também sofrem os soldados, que recrutados em todos os estados da União, com as mesmas bazófias do futuro, vão para servir de escravos a mando de braços bordados de galardões, chibateados da manhã à noite (BARBOSA, op. cit. p. 256).

É também um misto de denúncia dos poderosos do mundo dito civilizado em oposição da vida sofrida do homem comum em uma terra sem lei e sem ordem. Visão semelhante a sua é a do inglês Henry Whistler, que em 1654 se referia desta forma ao relatar o fato da Inglaterra mandar para a colônia caribenha de Barbados seus degredados: "Esta ilha é um monte de estrume onde a Inglaterra despeja seu lixo: vadios e prostitutas e outras pessoas do tipo são as que em geral trazem para cá” (LINEBAUGH, p. 26).

A Amazônia adquire então aspecto parecido ao descrito por Whistler, um depósito para o "lixo”, para o “estrume social” indesejado e produzido pelas contradições do modelo republicano, que estava em transição de um renegado passado monárquico e escravista que teimava em permanecer com alguns traços nos comportamentos e feições de parte da população. Junto a isso, havia ainda o processo de urbanização e remodelamento da capital da República que vinham sendo implementados desde a última década do XIX (Cf.: CARVALHO, 1995; ROCHA, 1995), bem como as políticas de saúde pública com a vacinação obrigatória (Cf.; CUKIERMAN, 2007; CHALHOUB, 1996).

Estes sujeitos desterrados eram os homens e mulheres que, nos dizeres de Euclides da Cunha, “levavam a doloríssima missão de desaparecer” quando foram condenados ao desterro no Acre, a "Sibéria tropical” (ver charge abaixo). Região vista como um local adequado aos recalcitrantes, por ser essa região considerada erma, distante, vazia, sem civilização, sem cultura constituída e, portanto, sem história. E o Acre, apenas "uma vaga expressão geográfica, um deserto empantanado, a estirar-se sem limites” (Cunha, 2000). 


\section{GEOGRAPHIA POLITICA}

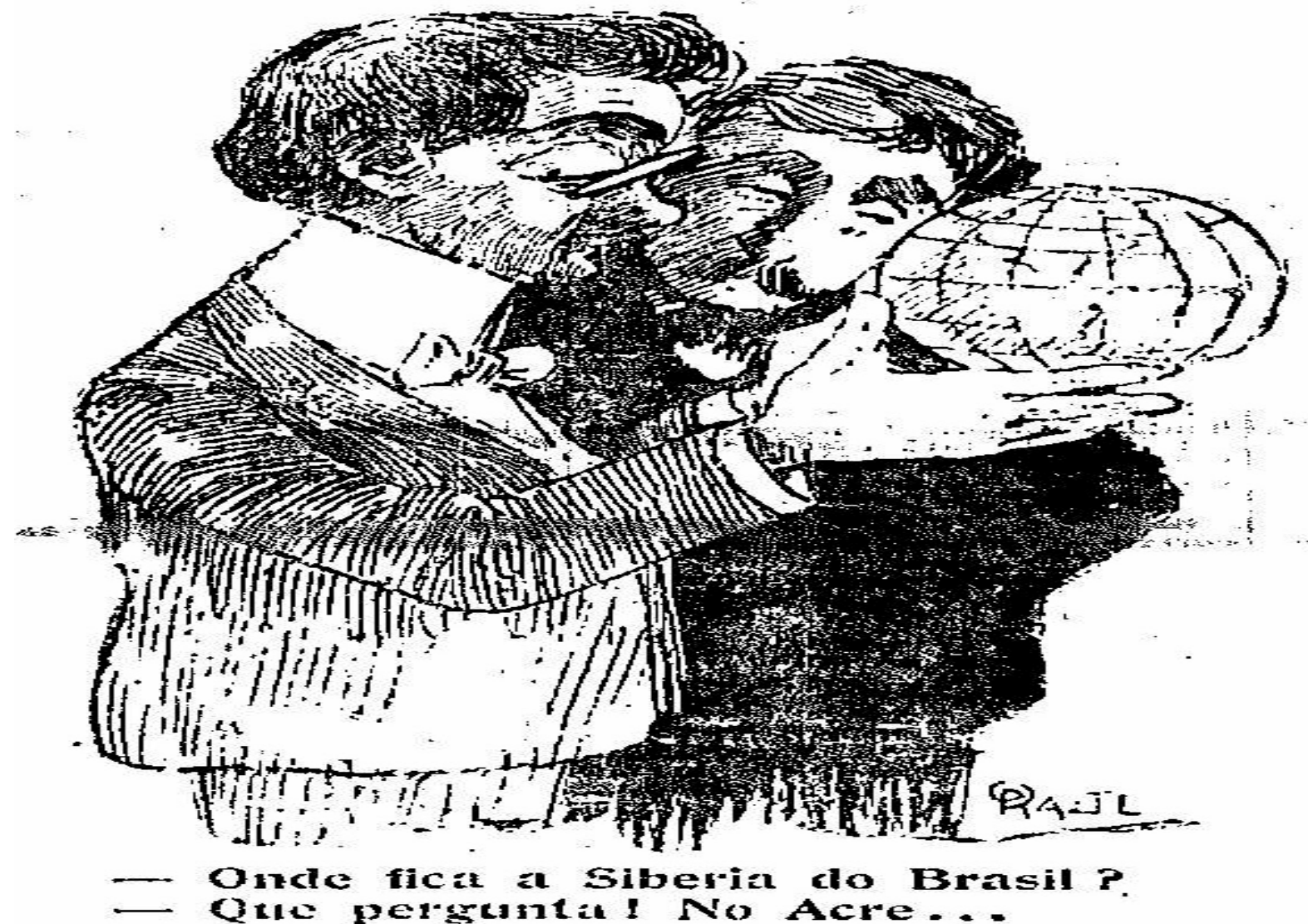

Charge 02: JORNAL DO BRASIL. Geographia política, ano XIII, no 334, 29/11/1904, p. 01. Acervo da Fundação Biblioteca Nacional.

Neste sentido, a natureza amazônica com sua grandiosidade, seus “vazios” demográficos e seus perigos, seria uma mãe disciplinadora para os filhos rebeldes da Nação, que iriam ser "polidos” nas suas brutezas pela natureza e amaciados pelas dificuldades de adaptação que ela ofereceria àqueles que também "chegam sem ser convidados” (CUNHA, 1998).

Foram então condenados a viver, - ou morrer —, no Acre, entre uma "vaga população erradia e dispersa, perdida em um recanto selvagem da Amazônia”, como se refere Oliveira Vianna (Oliveira Viana, 146). Uma população que no entendimento deste sociólogo era formada majoritariamente por "cangaceiros tumultuários; jagunços explosivos e turbulentos; sertanejos rebeldes e indomáveis” (idem, p. 147). Se o Acre era assim, nada mais justo no imaginário de algumas personalidades da época em mandar pessoas com semelhantes predicados para viverem longe da república imaginada e sonhada. Foi assim que embarcaram em navios-prisões grupos heterogêneos de homens e mulheres para uma viagem sem volta, para um destino cruel, onde o horizonte que se apresentava era ou a morte ou o isolamento na "Sibéria tropical”. 
Para os sobreviventes adventícios, restava o exílio na “própria” terra, num local afastado e desconhecido que paradoxalmente também era uma "outra” terra. Os defensores dos desterros acreditavam que somente por meio de um trabalho rigoroso e severo é que aqueles homens rudes e mulheres licenciosas teriam a oportunidade de abrandarem suas brutezas e práticas condenáveis pelo olho do poder civilizatório e policialesco que se tentava implantar na capital da nação brasileira. Vale lembrar que os verbos polir e policiar possuem a mesma matriz semântica. Neste sentido o Estado intentava exercer polimento e policiamento das mentes desviadas, dos corpos indômitos e das práticas condenáveis. Visava enquadrar os indivíduos para serem sujeitos “bons e do bem”, monopolizando a violência legal para instaurar a ordem imaginada.

\section{Considerações finais}

Neste breve artigo intentamos trazer ao presente algumas questões relativas aos desterros implementados pelo Estado brasileiro como punição e penalização aos "sujeitos incômodos”, considerados perigosos ao convívio social que se idealizava como correto na capital da república no início do século XX. Como afirmou certa vez Marc Bloch (2001), não existe passado morto. Existe passado esquecido - consciente e inconscientemente inacessível ou perdido. No caso dos desterrados, suas expulsões traziam a marca do isolamento, da tentativa de escondê-los nas selvas longínquas da Amazônia acreana. Além do banimento físico, se procurou bani-los da memória, apagar suas identidades e seus dramas à posteridade.

Se lembrarmos Andréas Huyssen (2000), diz ele que o lugar da memória em uma sociedade qualquer é determinado por uma rede discursiva complexa, portadora de aspectos rituais, míticos, históricos, políticos e psicológicos. Assim sendo, os acontecimentos do Rio de Janeiro envolvendo os desterros e os sujeitos por elas atingidos, tem relevância dada a presença dessa ampla rede discursiva atuando na imprensa da época, no sistema penal e policial do Estado brasileiro, nas representações em torno de uma história nacional, da República e da Nação. Pode se atestar que aqueles homens e mulheres desterrados não foram condenados somente pelo aparato repressivo republicano através do estado de sítio, mas acima de tudo condenados e punidos pela nova ordem política, moral e citadina que as elites brasileiras intentavam impor na capital do país. 


\title{
FROM RIO DE JANEIRO TO TROPICAL SIBERIA: Prison and exile to Acre in the years of 1904 and 1910.
}

\begin{abstract}
This article tries to bring to light some obscure aspects of two events that marked the Brazilian Republic in the beginning of the twentieth century: the Revolt of the Vaccine (1904) and Revolt of Sailors (1910). Some of these aspects are related to the exile, which were used as punishment by the Brazilian State after the end of those two events that occurred in Rio de Janeiro. What remains unclear is why these men and women were condemned to exile and who led the Brazilian state to send them to the Territory of Acre, in the Amazon. Therefore, it is aimed to set within the standards and legal frameworks adopted at the time the intentions and meanings of such measures, discussing also the meanings of perceptions of imposed punishments on the displaced people in terms of republican order, and the purpose - symbolic and practical - of sending these people away to the "confines" of the Amazon, in Acre.
\end{abstract}

Key words: Exile. Revolt of the vaccine. Revolt of sailors. Amazon. Acre.

\section{Referências}

BARBOSA, Rui. Obras completas. Volume XXXVIII, tomo I. Fundação Casa de Rui Barbosa: Rio de Janeiro, 1911.

BLOCH, Marc Leopold Benjamin. (2001). Apologia da história ou o ofício do historiador. Tradução de André Telles. Rio de Janeiro. Jorge Zahar editores.

CARVALHO, Lia Aquino de. Contribuição ao estudo das habitações populares: Rio de Janeiro - 1886/1906. Coleção Biblioteca Carioca. Rio de Janeiro: Secretária Municipal de Cultura, 1995.

CARVALHO, José Murilo de. Os bestializados da República: o Rio de Janeiro e a República que não foi. 03 ${ }^{\mathrm{a}}$ ed. São Paulo: Companhia das Letras, 2004.

CHALHOUB, Sidney. "Medo branco de almas negras: escravos libertos e republicanos na cidade do Rio”. In Revista Brasileira de História, São Paulo: ANPUH/Marco Zero, vl. 08, nº 16, pp. 83/105, 1988.

Sidney. Cidade febril: cortiços e epidemias na Corte imperial. São Paulo:

Companhia das Letras, 1996.

CUKIERMAN, Henrique. Yes, nós Temos Pasteur - Manguinhos: Oswaldo Cruz e a História da Ciência no Brasil. Rio de Janeiro: Faperj/Relume Dumará, 2007.

CUNHA, Euclides da. Um paraíso perdido. Rio Branco: Fundação Cultural do Estado do Acre, 1998.

. A margem da história. Rio Branco: Fundação Elias Mansour, 2000. 
FOUCAULT, Michel. Vigiar e Punir: historia da violência nas prisões. Petrópolis: Vozes, 1987.

HUYSSEN, Andréas. Seduzidos pela memória: arquitetura, monumentos, mídia. Rio de Janeiro: Aeroplano, 2000.

LINEBAUGH, Peter. “Todas as montanhas atlânticas estremeceram”. In: Revista Brasileira de História, São Paulo: ANPUH/Marco Zero, nº 06, pp. 07/46, 1984.

LEVI-STRAUSS, Claude. Tristes trópicos. Tradução de Rosa Freire D’Aguiar. São Paulo: Companhia das Letras, 2001.

NASCIMENTO, Álvaro Pereira do. A ressaca da marujada: recrutamento e disciplina na Armada Imperial. Rio de Janeiro: Arquivo Nacional, 2001.

NEEDELL, Jeffrey. Belle èpoque tropical: sociedade e cultura de elite no Rio de Janeiro. São Paulo: Cia. das Letras, 1993.

OLIVEIRA VIANNA, Francisco. Pequenos estudos de psychologia social. 03 ${ }^{\mathrm{a}}$ edição, Rio de Janeiro: Companhia Editora Nacional, 1942.

PEREIRA, Leonardo Affonso de Miranda. As barricadas da saúde: vacina e protesto popular no Rio de Janeiro da Primeira República. São Paulo: Fundação Perseu Abramo, 2002.

ROCHA, Oswaldo Porto. A era das demolições: cidade do Rio de Janeiro - 1870/1920.

Coleção Biblioteca Carioca. Rio de Janeiro: Secretária Municipal de Cultura, 1995.

TOCANTINS, Leandro. Amazônia: natureza, homem e tempo. 02ª edição. Rio de Janeiro: Civilização brasileira/Bibliex, 1982. 